Sains Malaysiana 48(1)(2019): 1-6

http://dx.doi.org/10.17576/jsm-2019-4801-01

\title{
Gastric Emptying and the Enzymatic Activity in the Stomach of Amphiprion ocellaris Fed on Artificial Diet
}

(Pengosongan Perut dan Aktiviti Enzim dalam Perut Amphiprion ocellaris yang Diberi Diet Buatan)

\author{
Mei Ling Khoo, Simon Kumar DaS* \& MaZlan ABD. GHaffar
}

\begin{abstract}
This study aims to elucidate the gastric emptying process of clownfish fed on artificial diet using two gastric evacuation models and to determine the pepsin activity in the digestion process in relation to feeding time. Regression analysis was used to evaluate the adequacy of 2 models; Anderson's $\left[S_{t}=S_{o}\left(1-S_{o}{ }^{(\alpha-1)} \rho(1-\alpha) t\right)^{1 /(1-\alpha)}+\xi\right]$ and Grove's model $\left[S_{t}=\right.$ $\left.\left(S_{o}^{\alpha}-\alpha K t\right)^{1 / \alpha}\right]$, in describing the gastric emptying rate. Grove's model provided a better fit with higher $r^{2}$ value, with the calculated parameters of maximum meal size at time $0\left(S_{0}\right)=0.195 \mathrm{~g}$ and gastric emptying rate $(\mathrm{K})=0.0165 \mathrm{~g} \mathrm{~h}$. There was no initial delay phase as predicted and the evacuation followed a curve. Pepsin activity in the stomach showed rapid responses to food intake, where activity was detected at $1 \mathrm{~h}$ after feeding and reached its peak at $2 \mathrm{~h}$ after feeding. Pepsin activity decreased since then until the 12th h after feeding where it reached the lowest point. An increase of pepsin activity was detected later, where a small boost was detected at $24 \mathrm{~h}$ after feeding to digest the remaining food item in the stomach before the pepsin secretion decreased and maintained at pre-feeding level. Fast response of digestive enzyme in stomach implied that clownfish is equipped to utilize infrequent and irregular meals effectively.
\end{abstract}

Keywords: Amphiprion ocellaris; evacuation model; gastric digestion, pepsin activity

ABSTRAK

Kajian ini bertujuan untuk menjelaskan proses pengosongan perut ikan badut yang diberi diet buatan dengan menggunakan dua model pengosongan gastrik dan untuk menentukan hubungan antara aktiviti enzim pepsin dalam proses pencernaan dengan masa selepas makan. Analisis regresi digunakan untuk menentukan ketepatan dua model; model Anderson $\left[S_{t}=S_{o}\left(1-S_{o}{ }^{(\alpha-1)} \rho(1-\alpha) t\right)^{1 /(1-\alpha)}+\xi\right]$ dan model Grove $\left[S_{t}=\left(S_{o}^{\alpha}-\alpha K t\right)^{1 / \alpha}\right]$, dalam penentuan kadar pengosongan perut selepas makan. Model Grove lebih sesuai kerana mempunyai nilai r yang lebih tinggi dengan parameter yang dikira merupakan saiz hidangan maksimum pada masa $0\left(S_{0}\right)=0.195 \mathrm{~g}$ dan kadar pengosongan perut $(\mathrm{K})=0.0165$ $g$ per jam. Tiada fasa lewat pada permulaan proses penghadaman seperti yang dianggarkan dan pengosongan perut adalah sejajar dengan lengkungan. Aktiviti enzim pepsin dalam perut menunjukkan tindak balas yang pantas terhadap pengambilan makanan dengan aktiviti pepsin dikesan seawal 1 jam selepas makan dan mencapai kemuncaknya pada masa 2 jam selepas makan. Aktiviti pepsin kemudiannya semakin menurun sehingga mencapai tahap terendahnya pada jam 12 selepas makan. Selepas itu, aktiviti pepsin meningkat semula dan terdapat rangsangan kecil dalam rembesan enzim yang dikesan pada 24 jam selepas makan. Aktiviti pepsin kemudiannya menurun semula kepada tahap sebelum makan. Tindak balas yang cepat terhadap pengambilan makanan menunjukkan ikan badut mampu menghadapi keadaan pembekalan makanan yang tidak menentu dengan berkesan.

Kata kunci: Aktiviti pepsin; Amphiprion ocellaris; model pengosongan; penghadaman gastrik

\section{INTRODUCTION}

The members of the clownfish (Amphiprion spp.) are one of the most demanding ornamental fish species in the aquarium trading (Wabnitz et al. 2003). In Malaysia, the supply of the clownfishes is dependently on the wild catch, thus increasing the potential of the fish being over-exploited (Cato \& Brown 2003; Chapman 1997). It is unfortunate that the studies on Malaysian pomacentrids are lacking, or only focused mainly on the reproduction biology (Liew et al. 2006; Sin et al. 1994). Studies in fish digestive physiology are of primary importance to set up nutritional protocols responsive to the metabolic capabilities of feed utilization of targeted species (Smith 1989). Digestion of the fish depends upon both the physical state of the food and the kind and quantity of enzymes in the digestive tract (Fänge \& Grove 1979), where the ability of fish to digest a particular component of diet can be ascertained by investigating the complement of digestive enzymes present along the digestive tract (Palanisamy 1989).

Clownfish Amphiprion ocellaris is omnivorous in nature and consume a wide variety of larva prey and algae (Fautin \& Allen 1992; Myers 1999; Sano et al. 1984). To achieve optimal digestion and utilization of fish feed for this species, the food need to be palatable and be 
size appropriate corresponding to its natural food items. Understanding the rate of digestion allows the prediction of return of appetite under given conditions and diets in captivity (Riche et al. 2004). Investigation of the secretory response time would help establish a better insight of its temporal digestive abilities, which in turn allows optimal feeding frequency to be predicted; crucial information for developing suitable regimes with maximum food intake and feed efficiency (McCarthy et al. 1993; Uys et al. 1987; Windell et al. 1972). Therefore, this paper aims to describe the digestion process of clownfish which focused on initiating the gastric emptying rates and the temporal changes in the enzyme pattern during digestion.

\section{MATERIALS AND METHODS}

\section{THE EXPERIMENTAL FISHES}

Thirty two fishes were bought, quarantined and maintained at condition close to their natural habitat (temperature $27^{\circ} \mathrm{C}$, salinity 28-30ppt) (Fautin \& Allen 1992; Maison \& Graham 2015) and were acclimatized with feeding of artificial diet (Sanyu Marine XP, containing 42\% of crude protein and $5 \%$ of lipid) for a week. Subsequently, the fishes were deprived for food for $72 \mathrm{~h}$ to completely empty the stomach contents. The fishes were then fed to satiation and the exact amount of pellets eaten by each fish was recorded. They were slaughtered at selected time. i.e. $0,1,2,4,8,12,16,20,24,28,32$ and 36 h post feeding and their stomach were separately removed. The contents of the stomach were weighed to the nearest $0.001 \mathrm{~g}$ and the data was used to model for gastric emptying rates. The stomach tissue were rinsed and then kept in the freezer at $-20^{\circ} \mathrm{C}$ for further enzyme studies.

\section{MODELLING OF GASTRIC EMPTYING RATES}

Collected data on the gastric evacuation are described by a range of mathematical models namely the power equation model based on Jones (1974):

$$
\mathrm{dS} / \mathrm{dt}=-\rho \mathrm{S}^{\alpha}
$$

S is the weight of total stomach content; and $\rho$ and $\alpha$ are the parameters to be estimated. $\rho$ was extended as a function of explanatory variables, where the effects of the variables are explored separately.

The equation was further developed to describe the emptying curve for a whole meal which forms a bolus or a simple item with similar shape but varying in sizes by Grove et al. (1985):

$$
\mathrm{S}_{\mathrm{t}}=\left(\mathrm{S}_{\mathrm{o}}^{(1-\alpha)}-\alpha \mathrm{Kt}\right)^{1 / 1-\alpha}
$$

where $\mathrm{S}_{\mathrm{t}}$ is total stomach content at time $\mathrm{t}$ after ingestion of meal size $\mathrm{S}_{\mathrm{o}}$, and $0 \leq \mathrm{S}_{\mathrm{o}} \leq \mathrm{S}_{\max }$.
Anderson $(1999,1998)$ then discovered that gastric evacuation can be described as a simple power model with an exponent of 0.5 , which is unaffected by meal size and expanded the model by complete integration of (1) from time 0 to $t$ as;

$$
\mathrm{S}_{\mathrm{t}}=\mathrm{S}_{\mathrm{o}}\left(1-\mathrm{S}_{\mathrm{o}}{ }^{(\alpha-1)} \rho(1-\alpha) \mathrm{t}\right)^{1 /(1-\alpha)}+\xi
$$

where $\mathrm{S}_{\mathrm{t}}$ is total stomach content at time $t$ after ingestion of meal size $\mathrm{S}_{\mathrm{o}}$; and $\xi$ is the random error term. In their study, the square root model version is incorporated in (3) and the gastric emptying rate constant, $\rho$ (GER) was estimated by non-linear regression of (3). These two equations (2 \& 3) are used for the comparative study of the digestion process in this study to discover the best fit for the gastric emptying of the clownfish.

Non-linear regression was used to estimate parameters of a non-linear model using MicroCalOrigin ${ }^{\mathrm{TM}}$ software programme for this study. The programme uses the Levenberg-Marquardt iterative method (Hashim et al. 2018; Mazlan 2001), utilizing non-linear procedures to examine the starting value specifications of the parameters and evaluate the Chi square value at each combination of values to determine the best set of values to start the iterative algorithm.

\section{MEASUREMENT OF ENZYME PEPSIN ACTIVITY}

Stomach samples obtained from the method described earlier were homogenized individually in ice cold 50 $\mathrm{mM}$ tris-HCL buffer; $\mathrm{pH7.4}$. The homogenate was then centrifuged at $5500 \mathrm{~g}$ for $5 \mathrm{~min}$ at $4^{\circ} \mathrm{C}$ before removing the supernatant to be stored at $-20^{\circ}$ prior to analysis. Total protein content of supernatant was determined using Bradford assay (Bradford 1976), using bovine serum albumin as the standard. The standard curve of BSA protein standard prepared was $\mathrm{y}=0.0144 \times-0.0234$ (Figure 1), which was used to calculate the mg protein from the gastric samples.

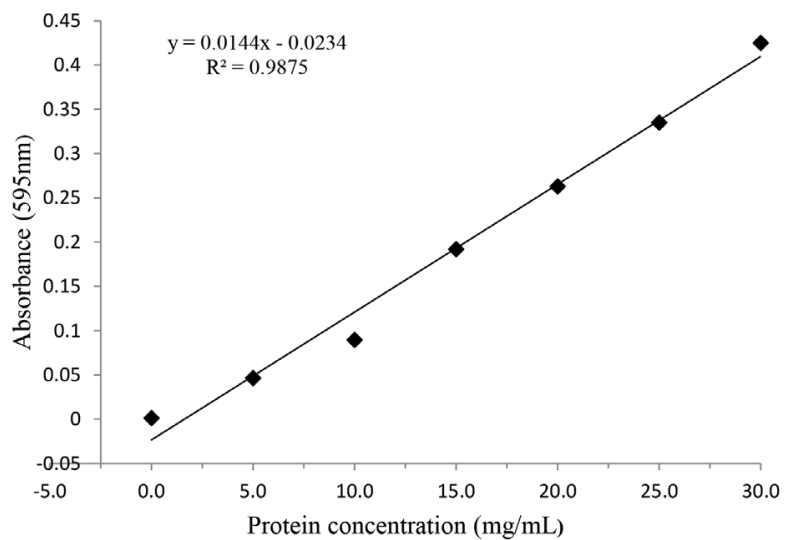

FIGURE 1. Standard curve for BSA protein assay 
The pepsin activity assay was determined using the Worthington (1993) assay, where pepsin activity was estimated using $2 \%$ haemoglobin in $0.06 \mathrm{~N} . \mathrm{HCl}$ as substrate. A total of $100 \mu \mathrm{L}$ enzyme extract in $0.01 \mathrm{~N} . \mathrm{HCl}$ was incubated at $37^{\circ} \mathrm{C}$ with $500 \mu \mathrm{L}$ of substrate for 10 min. The reaction was terminated by adding $1 \mathrm{~mL}$ of $5 \%$ trichloroacetic acid (TCA) and left for 5 min before centrifuging at $12000 \times \mathrm{g}$ for $5 \mathrm{~min}$. Absorbance was recorded at $280 \mathrm{~nm}$. For blank reading, TCA was added to substrate prior to the addition of enzyme extract. Specific activity (U) was expressed as:

$\begin{aligned} & \text { Absorbance value at }- \text { Absorbance value at } \\ & 280 \text { (supernatant) } \quad 280 \text { (blank) }\end{aligned}$
10 minutes $\times$ mg protein

\section{RESULTS}

\section{MODELLING OF GASTRIC EMPTYING RATES}

All stomachs were emptied within $36 \mathrm{~h}$ as predicted by Khoo and Mazlan (2014). Gastric evacuation rates (GER) for both equations were curvilinear and closely similar as shown in Figure 2, therefore both models are applicable. The Anderson model predicted a slightly smaller size of maximum food intake and slower emptying rate where the maximum meal size of $0.177 \mathrm{~g}$ with gastric emptying rate $(\rho) 0.012 \mathrm{gh}^{-1}$, whereas the Grove model predicted the maximum meal size of $0.196 \mathrm{~g}$ with gastric emptying rate $(\mathrm{K})$ of $0.016 \mathrm{gh}^{-1}$. Since the $\mathrm{r}^{2}$ value was higher, the simple power model from Grove et al. (1985) seems more accurate (Table 1).

\section{ENZYMATIC ACTIVITY IN THE STOMACH OF CLOWNFISH}

The patterns of specific pepsin activity are as shown in Figure 3. Total pepsin activity recorded in the stomach ranged from 8.77 to $52.36 \mathrm{Umg}^{-1}$ protein with average value of $30.64 \mathrm{Umg}^{-1}$. Pepsin activity was detected on the first hour after feeding, increases and reached its peak at $2 \mathrm{~h}$ after feeding before undergoing a sharp decline to its lowest peak at $12 \mathrm{~h}$ after feeding. It then recovered and reached a second but lower peak at the 24 th $\mathrm{h}$ after feeding before the activity was maintained at a rather constant level after $28 \mathrm{~h}$ prior to feeding. The secretory patterns resembled the digestive enzyme activity in African catfish, Clarias gareipinus (Uys et al. 1987) where pepsin activity was too detected as early as $1 \mathrm{~h}$ after feeding and reached its maximum at about $2.5 \mathrm{~h}$ prior to feeding before decreasing progressively after.

\section{DISCUSSION}

Gastric emptying process started earlier as predicted by previous works (Khoo \& Mazlan 2014). In studies where artificial feeds are concerned, a delay phase is usually
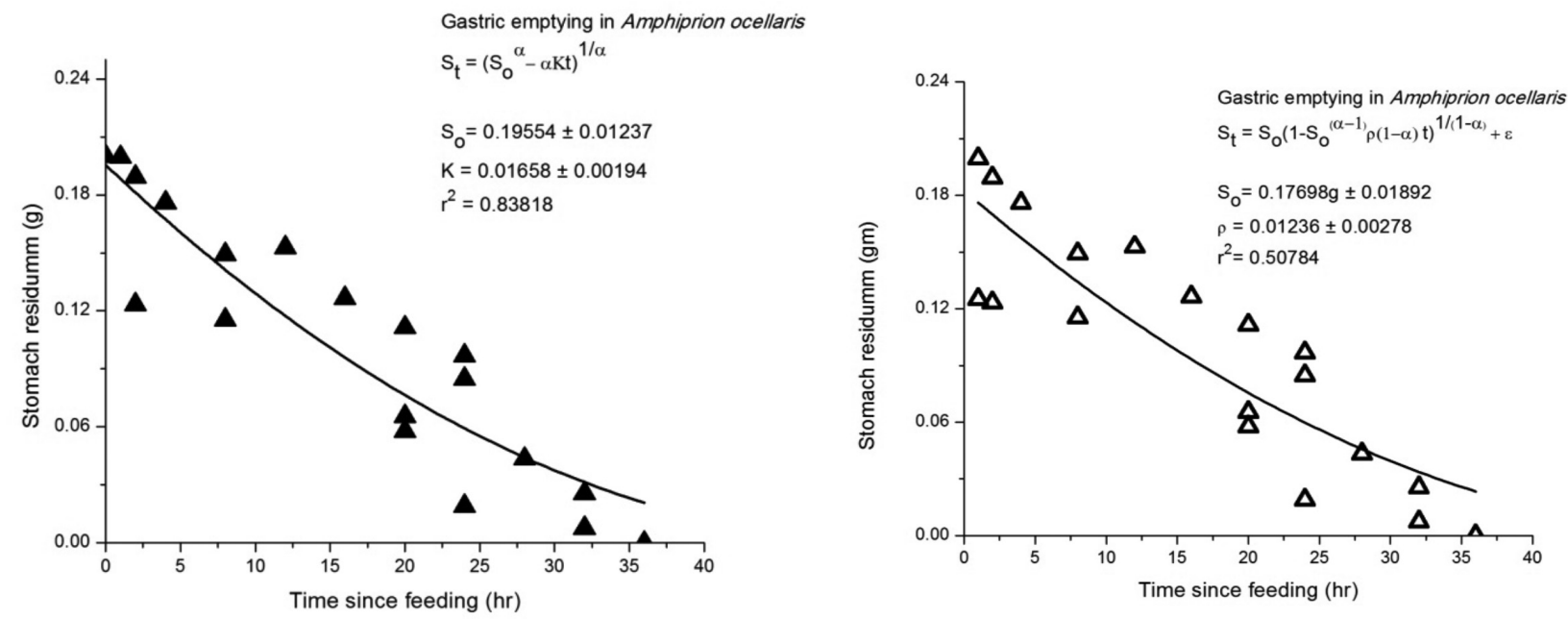

FIGURE 2. Gastric emptying curve of clownfish feeding on pellets using Grove's model (left) and Anderson's model (right)

TABLE 1. Comparison of gastric emptying rates between the two models used for clownfish fed on pellets

\begin{tabular}{|c|c|c|c|}
\hline Equation & $\begin{array}{c}\mathrm{S}_{\max } \text { or } \mathrm{S}_{\mathrm{o}} \\
(\mathrm{g})\end{array}$ & $\begin{array}{l}\text { K or } \rho \\
\left(\mathrm{g} \mathrm{hr}^{-1}\right)\end{array}$ & $r^{2}$ \\
\hline $\mathrm{S}_{\mathrm{t}}=\mathrm{S}_{\mathrm{o}}\left(1-\mathrm{S}_{\mathrm{o}}^{(\alpha-1)} \rho(1-\alpha) \mathrm{t}\right)^{1 /(1-\alpha)}+\xi$ (Anderson model) & $0.17698 \pm 0.01892$ & $0.01236 \pm 0.00278$ & 0.50784 \\
\hline $\mathrm{S}_{\mathrm{t}}=\left(\mathrm{S}_{\mathrm{o}}^{\alpha}-\alpha \mathrm{Kt}\right)^{1 / 1-\alpha}($ Grove model $)$ & $0.19554 \pm 0.01237$ & $0.01658 \pm 0.00194$ & 0.83818 \\
\hline
\end{tabular}




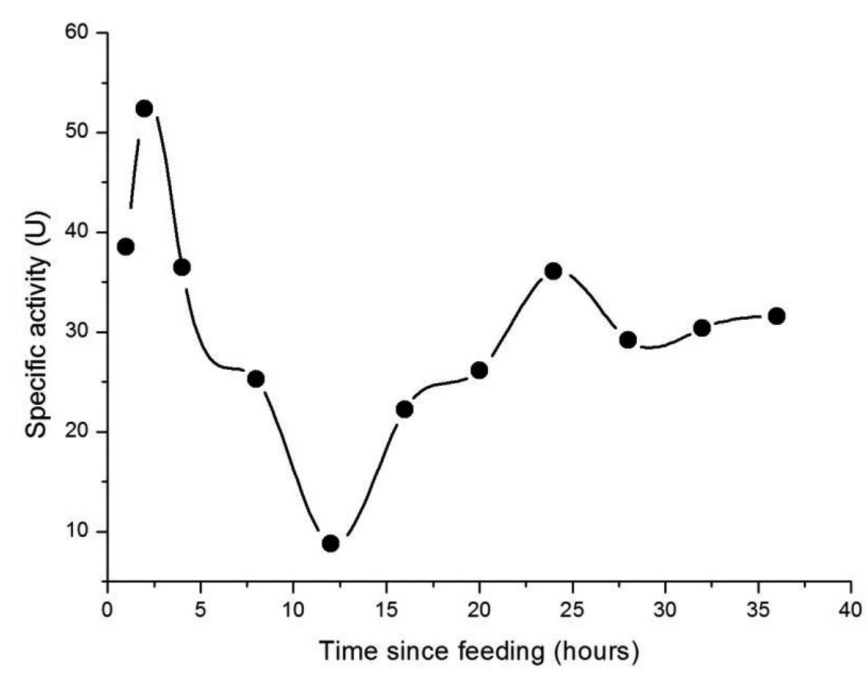

FIGURE 3. Changes in pepsin activity in the stomach contents of clownfish fed on pellets at selected time after feeding

detected as the food ingested needed to be soften before digested and this impose a demand of water intake which delays the digestion rate (Grove et al. 2001; Hughes \& Barrows 1990; Ruohonen et al. 1997). Dry pellets usually contained water level of less than $10 \%$ in contrast to the natural preys $(70-80 \%)$. Therefore, food needed to be moisten before digestion can start (Hughes \& Barrows 1990; Kristiansen \& Rankin 2001; Ruohonen et al. 1998). However, this is not the case in our studies where digestion was detected as early as $1 \mathrm{~h}$ after feeding. This might be due to the pellets absorbing moisture as soon as in contact with water, therefore fishes are likely taken moistened pellets before digestion take place. The gastric emptying time of $36 \mathrm{~h}$ were longer than the hybrid grouper, Epinephelus spp. $(\sim 15$ h) (Moumita et al. 2016, 2014) and the tropical snapper ( 20 h) (Mazumber et al. 2015). Although these fishes are of tropical origin, the difference in their feeding niches is probably effecting the gastric emptying time where evidence were reviewed that fish which have dissimilar food in nature have dissimilar gastric emptying time (Fänge \& Grove 1979).

This is the first report on the enzymatic activity in clownfish fed on artificial diet. The pepsin activity also showed no delay in the early phase similar to the gastric emptying curve, which indicated that the enzyme secretory appears to be induced by food intake. The gradual decrease after the 2 nd $h$ after feeding maybe caused by denaturation of enzymes, or most enzymes were being absorbed or bound to substrates and being actively evacuated from the stomach into the anterior intestine. This indicated that enzyme secretion in stomach of clownfish was limiting and not continuous. The small boost of enzyme secretion after 24th $\mathrm{h}$ prior to feeding to finish off the remaining food implied that enzyme secretion might be regulated by stomach distension as proposed by Smit (1968) in frogs (Rana sp.), and Western and Jennings (1970) in cottids (Cottus gobio) and brown trout (Salmo trutta). A smaller bolus of food created less distention of stomach wall which resulted in less enzyme secretion. Storage of secretory enzymes was reported by Caruso et al. (2008), Einarsson et al. (1996) and Uys et al. (1987) in starved Atlantic salmon, European eel and yearling catfish respectively at pre-feeding time $\left(\mathrm{T}_{0}\right)$ despite absence of food for $24 \mathrm{~h}$. The enzyme activity was not determined in this study however, the pepsin activity remained constant at $30 \mathrm{Umg}^{-1}$ after the 30 th $\mathrm{h}$ after feeding and that might suggest the pre feeding level of enzyme activity in the stomach of the clownfish.

The pepsin activity measured in this study is compared among others, non-congeneric to non-marine species as studies on the temporal changes in enzyme pattern during digestion are limited to only a few species namely, carp (Cyprinus carpio), Japanese eel (Anguilla japonica), African catfish (Clarias gariepinus) and European eel ( $A$. anguilla). The changes in the pepsin activity in stomach of clownfish followed closely to the protease activity in the stomach of African catfish with the maximum level of secretion at $2.5 \mathrm{~h}$ after feeding before decreasing as reported by Uys et al. (1987). Onishi et al. (1976, 1973a, 1973b) and Palanisamy (1989) reported a peak protease activity after $5 \mathrm{~h}$ prior to feeding for carp and grey mullet (Liza parsia), respectively, while Takii et al. (1985) discovered that maximum protease activity in Japanese eel is achieved only $12 \mathrm{~h}$ after feeding. The slow secretory response time in the species aforementioned studies will be at disadvantage should there be any irregular supply of food item or infrequent meals. In comparison, the clownfish has a more rapid digestive enzyme secretory response which may imply that clownfish is equipped to cope with infrequent and irregular meals effectively.

\section{CONCLUSION}

Gastric emptying of clownfish followed a curve, with no delay phase detected. The pepsin activity was at its peak 
at $2 \mathrm{~h}$ after feeding before a gradual decrease and a small boost of enzyme secretion as observed at 24th h later feeding to finish off the remaining food in the stomach. The results in this study provided basic information on the gastric emptying process and its enzymatic activity on clownfish fed on artificial diet which will eventually give a better insight on how to manage this fish species in captive water. The underlying patterns of feeding and digestion rate found can be further improved to be used for future research aquaculture and fisheries management.

\section{ACKNOWLEDGEMENTS}

The authors would like to thank the laboratory and field technicians of Ichthyology Lab, Universiti Kebangsaan Malaysia (UKM) for their efforts and support during this study. Thanks also to UKM for research grants GUP-2015$025 \&$ GUP-2017-023.

\section{REFERENCES}

Andersen, N.G. 1999. The effects of predator size, temperature and prey characteristics on gastric evacuation in whiting. Journal of Fish Biology 54: 287-301.

Andersen, N.G. 1998. Effect of meal size on gastric evacuation in whiting. Journal of Fish Biology 52: 743-755.

Bradford, M. 1976. A rapid and sensitive method for quantification of microgram quantities of protein utilizing the principle of protein dye-binding. Analytical Biochemistry 72: 248-254.

Caruso, G., Denaro, M.G. \& Genovese, L. 2008. Temporal changes in digestive enzyme activities in gastrointestinal tract of Europoean eel (Anguilla anguilla) (Linneo 1758) following feeding. Marine and Freshwater Behaviour and Physiology 41: 215-228.

Cato, J.C. \& Brown, C.L. 2003. Marine Ornamental Species: Collection, Culture, and Conservation. Ames: Iowa State Press.

Chapman, F.A., Fitz-Coy, S.A., Thunberg, E.M. \& Adams, C.M. 1997. United States of America trade in ornamental fish. Journal of the World Aquaculture Society 28: 1-10.

Einarsson, S., Davies, P.S. \& Talbot, C. The effect of feeding on the secretion of pepsin, trypsin and chromotrypsin in the Atlantic salmon, Salmo salar L. Fish Physiology and Biochemistry 15: 439-446.

Fänge, R. \& Grove, D.J. 1979. Digestion in fish physiology. Volume VIII. In Bioenergetics and Growth, edited by Hoar, W.S., Randall, D.J. \& Brett, J.R. Orlando: Academic Press Inc. pp 172-241.

Fautin, D.G. \& Allen, G.R. 1992. Anemone Fishes and their Host Sea Anemones, a Guide for Aquarists and Divers. Perth: Western Australian Museum. p. 160.

Grove, D.J., Genna, R., Paralika, V., Boraston, J., Hornyold, M.G. \& Siemens, R. 2001. Effects of dietary water content on meal size, food intake, digestion and growth in turbot, Scophthalmus maximus (L.). Aquaculture Research 32: 433-442.

Grove, D.J., Moctezuma, M.A., Flett, H.R.J., Foott, J.S., Watson, T. \& Flowerdew, M.W. 1985. Gastric emptying and the return of appetite of juvenile turbot, Scopthalmus maximus L. fed on artificial diets. Journal of Fish Biology 26: 339-354.

Hashim, M., Abidin, D.A.Z., Simon, K.D. \& Mazlan, A.G. 2018. Gastric emptying and food consumption of Scatophagus argus. AACL Bioflux 11(1): 278-287.
Hughes, S.G. \& Barrows, R. 1990. Measurement of the abilities of cultured fishes to moisten their digesta. Comparative Biochemistry and Physiology A96: 109-111.

Jones, R. 1974. The rate of elimination of food from the stomachs of haddock Melanogrammus eaeglefinus, cod, Gadus morhua and whiting Merlangius merlangus. Journal du Conseil/ Conseil Permanent International pour l'Exploration de la Mer 35(3): 225-243.

Khoo, M.L. \& Mazlan, A.G. 2014. Estimation of gastric emptying time (GET) in clownfish (Amphiprion ocellaris) using x-radiography technique. AIP Proceedings 1614: 624-628.

Kristiansen, H.R. \& Rankin, J.C. 2001. Discrimination between endogenous and exogenous water sources in juvenile rainbow trout fed extruded dry feed. Aquatic Living Resources 14: 359-366.

Liew, H.J., Ambak, M.A. \& Abol-Munafi, A.B. 2006. Embryonic development of clownfish Amphiprion ocellaris under laboratory conditions. Journal of Sustainable Science and Management 1(1): 64-73.

Maison, K.A. \& Graham, K.S. 2015. Status review report: Orange clownfish (Amphiprion percula). Report to National Marine Fisheries Service, Office of Protected Resources. p. 67.

Mazlan, A.G. 2001. Food consumption patterns and dietary digestibility of whiting (Merlangius merlangus L.) fed in laboratory conditions. Ph.D Thesis, University of Wales Bangor (Unpublished).

Mazumber, S.K., Mazlan, A.G. \& Simon, K.D. 2015. The effects of temperature on gastric emptying time of Malabar Blood Snapper (Lutjanus malabaricus, Bloch \& Schneider 1801) using X-radiography technique. AIP Conference Proceedings 1678: 020032-1-023332-4.

McCarthy, I.D., Houlihan, D.F., Carter, C.G. \& Moutou, K. 1993. Variation in individual food consumption rates of fish and its implications for study of fish nutrition and physiology. Proceedings of the Nutrition Society 52: 427-436.

Moumita, D., Mazlan, A.G. \& Simon, K.D. 2014. Temperature effect on gastric emptying time of hybrid grouper (Epinephelus spp.). AIP Conf. Proc. 1614: 616-618.

Moumita, D., Mazlan, A.G., Bakar, Y. \& Simon, K.D. 2016. Effect of temperature and diet on growth and gastric emptying time of the hybrid, Epinephelus fuscoguttatus $+\times$ E. lanceolatus 今. Aquaculture Reports 4: 118-124.

Myers, R. 1999. Miconesian Reef Fish: A Field Guide for Divers and Aquarists. Barrigada: Coral Graphics.

Onishi, T., Murayama, S. \& Takeuchi, M. 1976. Sequence of digestive enzyme levels in carp after feeding. III. Responses of protease and amylase to twice-a-day feeding. Bulletin of the Japanese Society for the Science of Fish 42: 921-929.

Onishi, T., Murayama, S. \& Takeuchi, M. 1973a. Sequence of digestive enzyme levels in carp after feeding. I. Amylase and protease of intestinal content, hepatopancreas and gallbladder. Bull. Tokai. Reg. Res. Lab. 75: 23-31.

Onishi, T., Murayama, S. \& Takeuchi, M. 1973b. Sequence of digestive enzyme levels in carp after feeding. II. Protease in activated and zymogen forms of intestine, hepatopancreas, gallbladder and spleen. Bull. Tokai. Reg. Res. Lab. 75: 33-38.

Palanisamy, K. 1989. Studies on the digestive enzymes of the cultivable grey mullet Liza parsia (Hamilton Buchanan, 1822). Ph.D. Thesis, Cochin University of Science and Technology (Unpublished).

Riche, M., Haley, D.I., Oetker, M., Garbrecht, S. \& Garling, D.L. 2004. Effect of feeding frequency on gastric evacuation and the return of appetite in tilapia Oreochromis niloticus (L.) Aquaculture 234: 657-673. 
Ruohonen, K., Grove, D.J. \& MclLroy, J.T. 1997. The amount of food ingested in a single meal by rainbow trout offered chopped herring, dry and wet diets. Journal of Fish Biology 51(1): 93-105.

Ruohonen, K., Vielma, J. \& Grove, D.J. 1998. Comparison of nutrient loss into the water from rainbow trout culture based on fresh Baltic herring, moist and dry diets. Aquaculture International 6: 441-450.

Sano, M., Shimizu, M. \& Nose, Y. 1984. Food Habits of Teleostean Reef Fishes in Okinawa Island, Southern Japan. Japan: University of Tokyo Press.

Sin, T.M., Teo, M.M., Ng, P.K.L., Chou, L.M. \& Khoo, H.W. 1994. The damselfishes (Pisces: Osteichthyes: Pomacentridae) of Peninsular Malaysia and Singapore: Systematic, ecology and conservation. Hydrobiologia 285: 49-58.

Smith, L.S. 1989. Digestive functions in teleost fishes. In Fish Nutrition. 2nd ed., edited by Halver, J.E. New York: Academic Press. pp. 405-407.

Smit, H. 1968. Gastric secretion in the lower vertebrates and birds. In Handbook of Physiology Section 6: Alimentary Canal, edited by Code, C.F. Washington: American Physiological Society. pp. 2791-2805.

Takii, K., Shimeno, S. \& Takeda, M. 1985. Changes in digestive enzyme activities in ee1 after feeding. Bulletin of the Japanese Society for the Science of Fish 51(12): 2027-2031.

Uys, W., Hecht, T. \& Walters, M. 1987. Changes in digestive enzyme activities of Clarias gariepinus (Pisces: Clariidae) after feeding. Aquaculture 63: 243-250.

Wabnitz, C., Taylor, M., Green, E. \& Razak, T. 2003. From Ocean to Aquarium. The Global Trade in Marine Ornamental Species. Biodiversity Series 17. Cambridge: UNEP-WCMC.

Western, J.R.H. \& Jennings, J.B. 1970. Histochemical demonstration of hydrochloric acid in the gastric tubules of teleosts using an in vivo Prussian blue technique. Comparative Biochemistry and Physiology 35: 879-884.

Windell, J.T., Hubbard, J.T. \& Horak, D.L. 1972. Rate of gastric evacuation in rainbow trout fed three pelleted diets. Progressive Fish-Culturist 34: 156-159.
Worthington, V. 1993. Worthington Enzyme Manual. Enzymes and Related Biochemicals Worthington Chemical. New Jersey: United States. p. 399.

\section{Khoo Mei Ling}

Marine Ecosystem Research Centre (EKOMAR)

Faculty of Science and Technology

Universiti Kebangsaan Malaysia

43600 UKM Bangi, Selangor Darul Ehsan

Malaysia

Simon Kumar Das*

School of Environmental and Natural Resource Sciences Faculty of Science and Technology

Universiti Kebangsaan Malaysia 43600 UKM Bangi, Selangor Darul Ehsan Malaysia

Marine Ecosystem Research Centre (EKOMAR) Faculty of Science and Technology Universiti Kebangsaan Malaysia 43600 UKM Bangi, Selangor Darul Ehsan Malaysia

Mazlan Abd. Ghaffar Institute of Oceanography and Environment Universiti Malaysia Terengganu 21030 Kuala Nerus, Terengganu Darul Iman Malaysia

*Coresponding author; email: skdas_maa@yahoo.com

Received: 15 September 2017

Accepted: 20 August 2018 